\title{
CORRECTING MiscarRiages OF JUSTICE: The Role of the Criminal Cases Review Commission THE BOWKer LECTURE, SEPTEMBER 28, 1999
}

\section{L.H. LEIGH*}

This article explains the origins and operation of the Criminal Cases Review Commission of the United Kingdom. The Commission was created in 1997 to investigate and respond to possible miscarriages of justice. The article explains how the Commission works and its jurisdiction. As well, the author describes the strengths and weaknesses of the workings of the Commission. This article was originally delivered as a lecture at the University of Alberta on September 28, 1999 as part of the Bowker Lecture series.
Cet article explique les origines et le fonctionnement de la Criminal Cases Review Commission (Commission d'ëude des causes criminelles) du Royaume-Uni. La Commission a été créée en 1997 pour ètudier les erreurs de justice éventuelles et y réagir. Cet article explique le fonctionnement et la juridiction de la Commission. $L$ 'auteur décrit en outre. les forces et les faiblesses des rouages de la Commission. Cet article a été présenté lors d'une conférence donnée à l'Université de l'Alberta le 28 septembre 1999 dans le cadre de la série de conférences Bowker.

TABLE OF CONTENTS

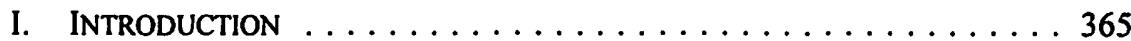

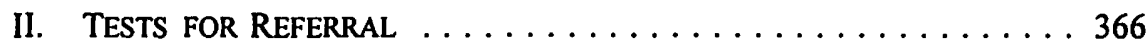

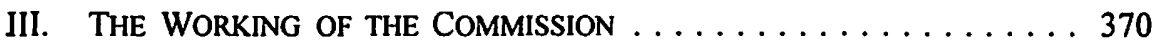

IV. AN EVALUATION OF THE COMMISSION's WORK ......... 375

\section{INTRODUCTION}

Human justice has always been recognized as fallible. In England, from the dawn of the modern era until 1907, the Sovereign, through the Royal Prerogative of mercy, had the power to grant a pardon where a person was wrongly convicted, or the power to commute sentence, usually from death to transportation. Under the Criminal Appeal Acts of 1907 and 1968, that power passed to the Home Secretary who was given power to refer cases of suspected miscarriage to the Court of Criminal Appeal, latterly the Court of Appeal, Criminal Division. The Criminal Cases Review Commission, which came into being on January 1, 1997 and which commenced operations on April 1 of that year, has assumed the review functions of the Home Secretary. The Commission was created as an independent body to investigate and respond to possible miscarriages of justice. It has as a mission the promotion of public confidence in a criminal justice system which, increasingly, has been the subject of bitter criticism.'

The Commission is an interdisciplinary body. Its members include lawyers, other persons having knowledge of the criminal justice system, and persons who, prior to appointment, had no such acquaintance. It includes accountants, scientists, a coroner,

B.A., LL.B. (Alberta), Ph.D. (London), Commission Member, Criminal Cases Review Commission. The author writes in his personal capacity and his views are not to be taken as those of the Commission.

I D. Rose, In The Name Of The Law (London: Random House, 1998). 
a psychiatrist, and a former deputy commissioner of the Metropolitan police. Its lawyer members have prosecution and defence experience, save for one member whose expertise is in the area of commercial law, a useful background when fraud cases are being considered. The mix of disciplines represented on the Commission is of the greatest value to the performance of its work. Commission members are assisted by case review managers and by a small administrative staff. It makes extensive use of high technology equipment. Indeed, it could not function effectively without it.

The jurisdiction of the Commission is wide. It has powers to review convictions made on summary conviction and on indictment, and sentences on indictment, where the matter was dealt with in criminal proceedings in England, Wales, and Northern Ireland. ${ }^{2}$ The Commission may also review findings of not guilty by reason of insanity and findings that a person was under a disability when he did the act or made the omission charged against him. ${ }^{3}$ The Court of Appeal may, furthermore, direct the Commission to investigate any matter in an appeal before it and to report to the Court. ${ }^{4}$ In so investigating, the Commission may determine to further investigate any related matter. $^{5}$

The Commission's terms of reference are thus very wide. The Commission may not, however, review convictions made by Courts-Martial or by Standing Civilian Courts since these procedures begin not by indictment but by charge. This is an undesirable state of affairs, particularly as it relates to civilians and service personnel who are convicted for what are essentially civil offences.

\section{TESTS FOR REFERRAL}

The Commission operates within limits set by respect for the trial process and for the integrity of findings of fact made at that stage. The Commission is not intended to usurp the basic fact-finding functions of trial courts at whatever level. Its power to refer matters is thus carefully circumscribed by a series of related sections of the relevant Criminal Appeal Acts.

The Commission may not refer a conviction, verdict, finding, or sentence unless it considers that there is a real possibility that the conviction, verdict, finding, or sentence would not be upheld were a reference to be made. ${ }^{6}$ Two matters are immediately

Criminal Appeal Act 1995, (U.K.), 1995, c. 35, ss. 9-12.

Ibid., ss. $9(5)$ and (6) and ss. 10(6) and (7). Because of procedural differences in Northem Ireland the statute does not speak of being under a disability but instead refers to a case where the jury has found that the person is unfit to be tried. The Criminal Appeal Act 1995 as originally drafted did not give the Commission power to review a verdict from Northern Ireland or England and Wales in the old form of "guilty but insane." This has been rectified by the Criminal Cases Review (Insanity) Act 1999, (U.K.), 1999 c. 25.

4 Criminal Appeal Act 1968, (U.K.), 1968, c. 19, s. 23A(1); Criminal Appeal (Northern Ireland) Act 1980, (U.K.), 1980, c. 47, s. 25A(1); Criminal Appeal Act 1995, supra note 2 at s. 15(1). In respect of the interviewing of witnesses this procedure replaces the former procedure of entrusting the case either to independent counsel or the Treasury Solicitor.

Supra note 2 at s. 2.

lbid. at s. 13(1)(a). 
apparent: first, that the Commission must consider what is meant by "real possibility," and second, that the Commission must, in order to do so, predict what the appellate court is likely to do in a particular case." The meaning of "real possibility" has attracted considerable Parliamentary debate. This formula is, however, impressionistic and therefore just as incapable of precise definition as other, hallowed legal formulae, such as "proximate cause." The Commission must proceed on an impressionistic basis, guided of course by the emphasis which this formula suggests.

The Commission's jurisdiction is, however, not a jurisdiction at large. It must, in the case of an application relating to conviction, be founded upon an argument or evidence not raised at trial or on appeal. In the case of sentencing, the Commission's jurisdiction is both broader and narrower. It is broader in that the Commission may refer a case on the basis of information not previously before the courts, which suggests a wider category than evidence. It is narrower in that the relevant argument must be on a point of law.

Furthermore, save where "exceptional circumstances" appear (a phrase not defined by statute) a person who seeks to have a conviction or finding reviewed must first have applied for leave to appeal. ${ }^{9}$ The basic scheme is thus one which requires certain procedural steps to have first been taken by an applicant, subject to a power in the Commission to proceed notwithstanding their lack where "exceptional circumstances" appear. In my opinion (which is not universally shared) "exceptional circumstances" does not apply where referral is sought as to sentence so that, in every such case, the applicant to the Commission must first have sought leave to appeal.

This stimulates three further orders of reflection. The first is that the Commission, in determining an application founded upon new evidence, must take a view as to how the Court of Appeal is likely to view that evidence. This follows from the requirement that the Commission consider whether the evidence is such as to raise a "real possibility" that the appellate court will quash the conviction. Applicants' legal advisers have sought to argue that the Commission may do no more than verify whether fresh evidence exists and, if so, must refer the case to the appellate Court which alone has the power to assess whether the evidence is relevant and credible and if so whether the evidence should be admitted in the interests of justice. ${ }^{10}$ The Commission's view, that it must operate a threshold test of admissibility, was upheld by the Divisional Court in ex parte Pearson." In this case, the Commission had to consider whether a medical doctor's report provided overwhelming or clear evidence in support of substituting a verdict of manslaughter for murder as required by the decision of the Court of Appeal

By appellate court is meant the Court of Appeal in England and Wales or Northern Ireland, or in summary conviction appeals, the Crown Court in England and Wales or the County Court in Northem Ireland.

- Supra note 2, s. 13(1)(b) and (c).

I Ibid., s. 13(2).

10 On the criteria for the admissibility of evidence before the Court of Appeal in England and Wales or Northern Ireland see, respectively, Criminal Appeal Act 1968, supra note 4, s. 23, and Criminal Appeal (Northern Ireland) Act 1980, supra note 4, s. 25.

" $\quad R$ v. Criminal Cases Review Commission, ex parte Pearson, [1999] 3 All E.R. 498. 
in $R$. v. Borthwick. ${ }^{12}$ The Court concluded that the Commission's findings could only be quashed if it acted unreasonably, or presumably if it was in breach of the rules of natural justice.

The second reflection is that the relevant sections of the Criminal Appeal Act 1995 are loosely drafted and have proved difficult for the Commission to interpret. Two illustrations will perhaps suffice.

The first of these concerns the standard applied by the Court of Appeal in determining whether to allow an appeal. Section 2(1) of the Criminal Appeal Act 1968, as amended, simply provides that the Court of Appeal shall allow an appeal if it finds that the conviction is unsafe and shall dismiss the appeal in any other case. Formerly, the Court could allow an appeal where it thought that the verdict was unsafe or unsatisfactory. This earlier formula was thought to comprehend at least some cases where the verdict, though factually safe, was unsatisfactory in terms of procedural due process. ${ }^{13}$

The government and the Lord Chief Justice apparently thought that the changed wording would effect no difference to the court's powers and practices. The Court of Appeal, however, thought differently. In $R$. v. Chalkley the Court held that "unsafe" means "factually unsafe."'4 This, if illiberal, was at least clear. Almost immediately, however, the Court began to change tack. In $R$. v. Mullen the Court held that it was possible to regard as unsafe a conviction made after a trial which ought never to have taken place, notwithstanding that it was factually sound. ${ }^{15}$ It cannot be said with certainty that the exception to factual infirmity relates only to abuse of process cases, however - it may be wider. It may extend to all cases that shock the conscience. It may be restricted to cases of that character where the vice cannot be cured by reference to customary trial procedures. For present purposes it is perhaps enough to say that the law is manifestly uncertain and the predictive task of the Commission correspondingly hazardous. ${ }^{16}$

The second illustration concerns the meaning to be attributed to the phrase "an argument on a point of law" in its relation to sentence. ${ }^{17}$ Clearly, where a court imposes a sentence not provided for by statute, or so manifestly unreasonable that no competent tribunal could have passed it, an argument on a point of law arises. ${ }^{18}$ Such

[1998] 2 Crim. L.R. 274.

House of Lords Debates, May 15, 1995 at col. 311 per Lord Taylor of Gosforth C.J.

R. v. Chalkley and Jefferies, [1998] 2 W.L.R. 146 at 155.

R. v. Mullen, [1999] Crim. L. R. 561. This was a case where the presence of the accused in Britain was assured by an abuse of extradition procedures and where a timely motion in bar of trial on the basis of abuse of process would have been allowed.

In R. v. Popat (No.2), 1999, Times, September 7. The Court of Appeal criticised the Commission for preferring one line of Court of Appeal authority over another. This seems harsh, the more as the line of authority which the Commission followed was the more liberal and was not obviously flawed.

Supra note 2 at s. 13(1)(b)(ii).

$R$ v. Verrier, [1976] 2 A.C. 195; $R$ v. Ashdown (1974), 58 Cr. App. R. 339; R. v. Truro Crown Court, ex parte Warren, [1993] C.O.D. 294. 
an argument arises also where the judge sentences the accused in defiance of proper procedures. ${ }^{19}$ The Court has, however, held that a person who is sentenced in accordance with the tariff prevailing at the time of the offence cannot complain if the tariff is later modified in the direction of leniency. Tariffs change, partly as a result of statutory changes, partly as a result of changes in the climate of public opinion, and partly as a result of such operational factors as prison overcrowding. Such a person cannot be considered to be a victim of injustice. ${ }^{20}$

The second limb of the sentence jurisdiction, "new information," is at large. The word "information" must have been chosen in apposition to "evidence" and dispenses the Commission and the Court from adhering to strict rules of evidence. The principal case of this genre which the Commission has sent to the Court is one in which the sentencing court was misled concerning the accused's criminal record, to his detriment. $^{21}$

The third reflection concerns the uncertainty of standards which the Commission should apply. Criminal law, evidence, and procedure are in a constant state of flux. What should be the stance of the Commission where the law has evolved since conviction in a way more favourable to the applicant than that which applied when he was convicted?

In $R$. v. Campbell, the Court started from the premise that it should not allow an appeal simply because the law, after his conviction, evolved in a manner more favourable to him than that which applied at the time of his trial. ${ }^{22}$ In the celebrated case of $R$. v. Bentley, however, the Court departed to a degree from this approach. ${ }^{23}$ This was a conviction for murder against Bentley and Craig for the murder of a policeman. Bentley was in fact hanged for the offence. The Commission referred the matter to the Court of Appeal. Lord Bingham C.J. held that the Court, in reviewing an old conviction, must apply the substantive law as it stood at the time, without, as in this instance, regard to the statutory abolition of the felony-murder rule. Complicity is, however, entirely a matter of common law in England and the law now current is that which is to be applied. In words which may prove to be prophetic, Lord Bingham stated:

Where, between conviction and appeal, there have been significant changes in the common law (as opposed to changes effected by statute) or in standards of faimess, the approach indicated requires the court to apply legal rules and procedural criteria which were not and could not reasonably have been applied at the time. This could cause difficulty in some cases but not, we conclude, in this. ${ }^{24}$

R. v. Coleman [1999] E.W.J. No. 605 (C.A.), online: QL (EWJ). Here the judge having passed sentence which would have taken effect as concurrent sentences purported to make them consecutive in the absence of the accused and his counsel. 
This approach contrasts strangely with the willingness of the Court of Appeal to use its discretion to refuse leave to appeal out of time to individuals claiming that changes in the interpretation of the law produce the result that conduct for the underlying conviction did not, after all, constitute criminal offences. ${ }^{25}$ This particular willingness appears to owe more to expediency in the interests of finality of litigation than to any desire to do justice in the particular case. ${ }^{26}$

The attitude of the Court of Appeal presents the Commission with a further difficulty unforeseen when the legislation was passed: the Commission has no discretion to refuse to look at a conviction simply because of its age, though it does have a general discretion, the governing principles of which are nowhere defined, not to refer a case to the Court of Appeal. ${ }^{27}$ Such a case, when referred, is an appeal and the Court cannot refuse to deal with it. This appears to create a chink in the Court's selfprotective armour. It may be that the Court of Appeal will hold that the Commission ought not to refer a matter when it seems likely that the Court would exercise its discretion not to grant leave. Such a solution has an appeal on grounds of pragmatism, but it is not one with which an inferior jurisdiction, such as that of the Commission, could be expected to feel comfortable. For, after all, the result of such an exercise of discretion is to leave the applicant subject to a criminal conviction which he does not merit. As Lord Goddard C.J. noted many years ago, the relevant circumstance (in a fraud case) is not whether a man is a scoundrel, but whether he committed a criminal offence. ${ }^{28}$

\section{THE WORKING OF THE COMMISSION}

The Commission, as noted, assumed the functions of the Home Secretary in the review of criminal convictions. When the Commission was created the government may have assumed that the Commission would follow the working practices and procedures of the Home Office. The statute itself is largely silent on such matters. In fact, the Commission decided to develop its own working practices, proceeding to a degree, but only to a degree, by analogy with the practices of other bodies.

The Commission decided early that it would be proactive and not reactive. Whereas the Home Office received papers and occasionally instructed inquiries by others, Commission members and case workers are active in the field. There can be few

See $R$. v. Hawkins, [1997] I Cr. App. R. 234, dealing with the aftermath of $R$. v. Preddy, [1996] 3 W.L.R. 255 which held that the courts had misinterpreted aspects of the obtaining-by-deception offences over a twenty year period.

See $R$. v. Horsman, [1997] 2 Cr. App. R. 418: where a person pleads guilty to conduct which did not constitute the offence charged but which may have constituted another offence, the Court of Appeal cannot, when quashing a conviction, substitute another verdict. In such a case the Court by refusing leave effectively shuts off all recourse and leaves the applicant suffering the consequences of a conviction which should never have been made. If the applicant then comes to the Commission and the Commission refers the case, the Court of Appeal must hear and decide it. 
prisons in England, Wales, and Northern Ireland which we have not visited. The police and the Customs and Excise are becoming accustomed to one or another of us arriving to inspect documents and to secure exhibits. Judges and lawyers have been met with, and usually respond favourably to, requests for information. The Commission will travel to see witnesses. With older cases, a good deal of reconstruction, sometimes from fragmentary materials such as exhibits, trial notebooks, press cuttings, and participants' memories, becomes necessary.

The Commission both investigates and judges. In its investigative role the Commission's approach is inquisitorial. This need occasion no surprise. The same comment could be made of the police and of other law enforcement bodies. With deference to the opinion of others, no western procedural system appears to be either wholly inquisitorial or wholly adversarial. ${ }^{29}$ If there is novelty it lies in this: the Commission operates under a rule of openness and it requires from applicants the same openness and willingness to disclose inconvenient facts and considerations as from the state organs in the criminal justice system. The Commission needs to know whether there are considerations which dictate that a case should not be referred as well as considerations which point to referral. Applicants and their advisers, who are often used to operating in a culture where a defendant can still conceal uncomfortable facts at the investigation and trial phases, do not always appreciate how the Commission views these matters.

Internally, the Commission organizes its investigations as follows: the task of investigation is confided either to a case review manager or, exceptionally, to a Commission Member. In either case a Commission Member acts as an assigned Commission Member, and as such ensures that a case plan is drawn up, discusses that plan with the person investigating, and maintains oversight over the investigation. He or she will discuss problems as they arise, which may include the general thrust of the enquiry or specific problems which arise in the course of the enquiry.

The Commission may investigate a matter entirely by itself or it may also use the resources of other bodies. ${ }^{30}$ The Commission thus has close contact with forensic laboratories and with other forensic specialists. The Commission may, and often does, ask police forces and other law enforcement bodies for limited help, perhaps in locating and interviewing witnesses. In most cases the tasks of examining documents, and interviewing witnesses and applicants is performed by the Commission staff, one of whose number is an experienced former police officer who acts as an investigations adviser. Where specialist procedures such as ESDA and DNA testing are required, outside experts are engaged.

Some cases, however, are simply too large and too complicated for the Commission to investigate alone. In such cases the Commission may call upon the police for 
assistance. ${ }^{31}$ The Commission may require the appointment of an investigating officer to carry out the inquiries. Such a requirement may be to appoint an officer from the force which carried out the original enquiry, or it may be, and commonly is, a requirement to appoint an officer from another force. ${ }^{32}$ The Commission may then either accept the appointment or refuse to do so and require the appointment of another officer ${ }^{33}$ The scheme is thus one in which the Commission's requirement is followed by a nomination which the Commission may reject. In fact, such a situation has never arisen. ${ }^{34}$

The Commission does not ask the investigating officer simply to reinvestigate the case at large. Instead, a cooperative system has emerged. The Commission has a duty to supervise the inquiry. ${ }^{35}$ The inquiry takes the form of cooperative work within an agreed plan. The Commission will invite the Investigating Officer and his or her team to its offices to discuss the investigation and to delineate the tasks to be performed by the Investigating Officer and those to be performed by the Commission. Periodic meetings follow and the Investigating Officer submits a report containing witness statements, forensic reports where appropriate, and his or her conclusions. In turn, this report together with the results of the Commission's investigations, will form the basis of the Commission's decision in the case.

Early experience with such inquiries has been favourable. The police have shown themselves very willing to cooperate with the Commission. The system of focused inquiries and cooperative work makes efficient use of police and Commission time and resources. Police enquiries themselves have been marked by professionalism and objectivity. Fears expressed by some civil liberties groups that the Commission would become the prisoner of hostile police attitudes and that investigations would result in whitewashing have been shown to be unfounded, as some critics of the system have admitted. ${ }^{36}$ That is not to say that there are never tensions between individuals in the police service (some highly placed) and the Commission. Such tensions have been felt, in particular, over the publication by pressure groups and by defence lawyers of Commission statements of reasons and attached Investigating Officers' reports, something the Commission can do nothing to prevent. These tensions have not, however, been allowed to affect the Commission's work and the police have remained supportive.

Ibid., s. 21. Such a requirement requires the decision of at least three Commission Members: Sched. I, para. 6(3).

lbid., s. 19(4).

Ibid., s. 19(6)-(7).

The Commission has, however, set its face against appointing an officer from a contiguous force. This contrasts with the practice of the Police Complaints Authority. The Commission's policy has not been challenged by the police who also see the advantages of avoiding conflicts caused by emotional commitments.

Some of the fears expressed by civil liberties groups derive from experience with other bodies which did not supervise enquiries properly. 
The Commission has been given wide powers to require the preservation and production of documents and other material held by a public body, which may assist the Commission in the exercise of its functions. ${ }^{37}$ Unfortunately, the Commission has no powers to obtain information from foreign bodies. It cannot ask that letters rogatory be issued at its instance. ${ }^{38}$ The Commission has no such powers in respect of private bodies. $^{39}$ This is unfortunate because some private bodies hold records the production of which can be essential to the proper investigation of an application. Telephone companies provide an apt illustration: the police can, by way of a warrant, secure lists of calls made, but the Commission cannot. Furthermore, regulatory powers are often confided in such private sector bodies as the Law Society, the Stock Exchange, and the General Medical Council. The Commission can only obtain information from them if they consent to disclose it. There seems little doubt that the Commission will need to press for remedial legislation to enhance its powers.

Relations between counsel, solicitors and the Commission, are usually helpful, but an element of tension sometimes enters into the relationship. The Commission prefers applicants to be legally represented; a good lawyer can help to clarify issues, identify documents and other relevant evidence, and locate witnesses. Tensions can, however, arise at times from the adversarial tradition. Furthermore, solicitors do not always appreciate that an issue which they consider to be decisive in favour of a reference may not seem to be so to the Commission. Solicitors and pressure groups sometimes complain of delay in the development of cases and of the propensity of the Commission, as they see it, to spend too much time investigating aspects of cases which the critics consider to be of little importance. The Commission must, however, make its own judgement on these matters. The Commission investigates at public expense. If it does not do so thoroughly, a full investigation may not be done. And if the big issue identified by the applicant's solicitor does not appeal to the Court it may then be necessary to do yet further work with a view to a fresh reference. It is worth remembering that of the grounds advanced by the Commission for the reference in the Bentley case, those grounds upon which the Commission primarily relied did not arouse the Court's enthusiasm. It instead, allowed the appeal on grounds which the Commission thought to be but of secondary importance. ${ }^{40}$

I pass now to the decision stage. The statute requires that three Commissioners must agree before a case may be referred. In fact, save for cases identified as being manifestly without merit, in which case a negative decision is taken by one Commissioner, cases are brought before a panel of three whether the case review manager (or Commissioner so acting) considers that the case should be referred or not.

Supra note 2 at s. 17.

On mutual legal assistance see A. Bolt, "Mutual Legal Assistance" in J. Vervale, ed., Transnational Enforcement of the Financial Interests of the European Union (Groningen: Intersentia Law Publishers, 1999).

Contrast the Police and Criminal Evidence Act 1984 (U.K.), 1984, c. 60, ss. 8-13 which permit the issue of wartants to search for evidence at the instance of the police. The new Scottish Criminal Case Review Commission has much wider powers, consistent with the Scottish tradition which, in part, derives from a Continental inquisitorial root.

Bentley, supra note 23 . 
This allows for the possibility that the panel will disagree with the rapporteur as does indeed happen. Vigorous debate within Case Review Committees and between Committee members and case review managers is common. A report is sent to the panel with full supporting documentation. It is then for the panel to refer, not to refer, or to direct that further work be done. At this stage the Commission's functions are judicial in character. It has a decisive effect on the case if the decision is in the negative or if it serves as a filter if the case is to be referred. The appellate court will then finally determine the matter.

When the Commission considers that the application should be refused the panel will direct that a provisional decision be sent to the applicant so that he or she may respond. This takes the form of a full statement of reasons with supporting documentation. Such a statement of reasons is required by statute. ${ }^{41}$ Furthermore, the common law requires that disclosures of this character be sufficiently ample to enable the person affected to respond to the decision in an informed manner. ${ }^{42}$ The applicant is given adequate time in which to respond. His or her response may well lead to a change of opinion on the part of the panel.

If the case is to be referred, a statement of reasons is sent both to the court to which the reference is made and to every person who appears likely to the Commission to be a party to any proceedings on an appeal arising from the reference..$^{43}$ Such a reference constitutes an appeal and the appellants are at liberty to advance any ground which they wish, even though that ground has not been advanced by the Commission. ${ }^{44}$

There is something of a dispute within the Commission at the time of writing concerning the proper contents of a statement of reasons referring a case. My view is that the statement of reasons should contain a balanced account of the case, setting forward the reasons for making a reference, but not ignoring those reasons which militate against that course. I take that view because I think it important that the appellate court see that the Commission acts objectively. There is a political dimension here: I believe that the courts will most firmly support the Commission if they are convinced that it acts objectively and impartially. I also believe that in some cases it benefits the applicant, particularly where he or she is likely to apply for bail pending appeal, and where the court needs to be in full possession of the facts. The contrary view is that the purpose of a statement of reasons is simply to inform the court why the Commission refers the case and is not intended to canvass matters which are extraneous to that decision. Both views are, I hope, respectable and the Commission will have ultimately to make a choice between them.

4 Supra note 2 at s. 14(6).

$42 \quad R$ v. Home Secretary, ex parte Hickey (No. 2), [1995] I W.L.R. 734; R. v. Home Secretary, ex parte Cleeland, (July 25, 1996), case no. C0-2658-95 (C.A.).

43 Supra note 2 at s. 14(4).

44 Ibid., s. 14(5); contrast the position which obtains where leave has been granted (in the normal case) to appeal on some grounds but not on others. There, for the appeal to be argued on the rejected grounds a fresh application to that effect must be made by the applicant; $R$. $\mathrm{v}$. Cox and Thomas, [1999] 2 Cr. App. R. 6. 
The Commission is functus officio after it has communicated its decision. It may be involved in later procedures such as discovery, but only as a body from which discovery may be demanded and not as an originating party. ${ }^{45}$ The Commission's statement of reasons has no recognized part to play before the court at the hearing of the appeal. In fact, however, it is clear that the Court of Appeal, in particular, pays very close attention to the Commission's statements of reasons; often but not always the Court will express itself in flattering terms. Counsel in some cases simply redraft the Commission's grounds for referral and treat them as their own.

Time permits no more than a passing reference to the Commission's duty to investigate matters which the Court of Appeal refers to it. Such a reference enables the court to inform itself more fully than it otherwise could of matters which arise at and are required to be determined at, the appellate stage. Such references can involve a great deal of work - locating and interviewing witnesses, commissioning forensic enquiries, and the like.

\section{AN Evaluation OF THE COMmission's WORK}

Critical comment has concentrated upon two aspects of the Commission's functioning. The first concerns the Commission's record in respect of those cases with which it deals. The second concerns the Commission's capacity to deal with its workload in general.

There seems to be general satisfaction with the way in which the Commission handles those cases with which it deals. Reviews are carried out thoroughly, objectively and as speedily as possible, consistent with a thorough enquiry into applications. Some of the Commission's most stringent critics have admitted publicly that the Commission is doing its work well. The courts have been very supportive. The great majority of cases which the Commission refers succeed in the Court of Appeal. It has been suggested that the Commission only selects those cases for review which are manifestly likely to succeed, but that is untrue: unless factors which justify giving a case priority are presented to the Commission, such as illness or disability on the part of an applicant or his or her witnesses, cases take their place in the queue.

If it were asked why the Commission has been relatively successful in this aspect of its work, I would say that we benefit from the ability to investigate cases at public expense without, at least to date, any overt pressure to restrict expenditure. We benefit from being located in a small country. Most visits in the field can be done within one or two days, even where the matter originates from Northern Ireland. Legal advice and assistance is available for solicitors who advise applicants and that too is beneficial. The intervention of a good solicitor helps the Commission to manage the case in which he or she is engaged. And, of course, we work with the grain of the system, not across it. The Commission should have been much less effective if it had not been able to

Problems of document and exhibit management pose difficulties for the Commission which were not fully foreseen and are now having to be addressed. No one, when the Commission was established, thought of the Commission as a passive party to litigation. 
engage in constructive dialogue with the police and other agencies within the criminal justice system. A turning motion is sometimes better than a frontal attack, a humble truth not always appreciated by pressure groups.

The Commission has, however, not been as successful in managing its workload as we would wish. Fears were expressed when the Commission was created that too wide a jurisdiction was being conferred on it, and that we should not be asked to deal with sentence matters or convictions made before magistrates' courts. ${ }^{46}$ Certainly the government underestimated the establishment which the Commission would need. The Commission inherited a number of difficult cases from the Home Office which have taken time to clear. Happily, the Commission has been given additional resources, but these cannot immediately be made effective; it takes time to train caseworkers and one cannot simply send files to solicitors in private practice, without more, and expect work of sufficiently high standard to be done.

The vice, I am convinced, does not lie in our wide jurisdiction. Few summary conviction matters come before us, and they can usually be dealt with speedily because of a lack of materials on which to base a decision. It is perhaps not generally known that no tape recording or shorthand record is made of appeals by way of trial de novo. We can do little with them. Nor, if those cases are referred, can the Crown Prosecution Service, which may simply find itself obliged to offer no evidence. The Commission's work load is, however, primarily made up of the most serious criminal offences: murder, serious sexual offences (particularly of rape and sexual abuse within the family), and narcotics offences predominate. As for sentence, in an era of increasingly long sentences for serious crimes and associated confiscation orders and default sentences, it is surely right that there be some ultimate safeguard, just as there is for convictions.

The answer, then, does not lie in restricting the Commission's jurisdiction. It lies in its ability to develop practices which, within a framework of reasonable resource provision, will allow effective management of the case load. These are matters which are, at present, being actively addressed with some measure of success. On the other hand the new Human Rights Act $1998^{47}$ could certainly complicate the work of the Commission by introducing a wide range of new issues for us to consider. The justice system as a whole has scarcely begun to come to grips with the issues which this legislation will present.

And a final point. I began by noting that one of the Commission's functions is to promote confidence in the criminal justice system. Case investigations will, we hope, indicate what shortcomings there are in the criminal justice system, though there will always be something of a lag factor here. In turn, the Commission can make a contribution by making these shortcomings known to the Home Office and other interested bodies, either privately or through our Annual Report. While it is too early to evaluate these matters in any depth, it is clear that some historic police malpractices

$4 \quad$ Justice (Society), Miscarriages of Justice (London: Justice, 1994).

47 (U.K.), 1998, c. 42. 
(of which "verballing" 48 was but one) have largely disappeared. Police corruption, alas, never entirely disappears. On the other hand, we are becoming increasingly aware of advances in scientific techniques and the problems of evaluating them. Finally, and it is for a lawyer an uncomfortable reflection, we have been struck by the impact of poor legal representation on verdicts.

In all of this, the function of the Commission is modest. We are an ultimate safeguard. We cannot hope to compensate for all of the problems of the criminal justice system. Most cases, if they go wrong, do so at an early stage and rightly, primary attention must be focussed on the problems which arise there. But our function, if modest, is valuable and we may perhaps, with some slight verbal adaptation, claim Beccaria's justification for our own:

If by supporting the rights of mankind, and of invincible truth, I shall contribute to saving from the agonies of death, one unfortunate victim of tyranny, or of ignorance, equally fatal, his blessing and tears of transport will be an effective consolation for me.... ${ }^{49}$ statement as his words. 